\title{
Diversity of deciduousness and phenological traits of key Indian dry tropical forest trees
}

\author{
Chandra Prakash KushwahA ${ }^{1,2 *}$, Shri Kant TRIPATHI ${ }^{1,3}$, Gopal Shankar SINGH ${ }^{1}$, \\ Kaushlendra Pratap SINGH ${ }^{1}$ \\ ${ }^{1}$ Department of Botany, Banaras Hindu University, 221005 Varanasi, India \\ ${ }^{2}$ Present Address: Center for Environmental Science \& Technology, Banaras Hindu University, 221005 Varanasi, India \\ ${ }^{3}$ Present Address: Department of Forestry, Mizoram University, 796009 Aizawl, India
}

Keywords:

tropical dry forests /

deciduousness /

wood density /

leaf mass per area /

leaf strategy index

(Received 28 April 2009; accepted 5 September 2009)

\author{
Mots-clés : \\ forêts tropicales sèches / \\ défoliation / \\ densité du bois / \\ masse de feuilles par unité de surface / \\ index de stratégie de la feuille
}

\begin{abstract}
- In seasonally dry tropical forests deciduousness (leaflessness) is an important strategy of trees to survive in water stress period during summer. Deciduousness is a reflection of interacted effect of seasonal drought, tree characteristics and soil moisture conditions.

- The present study aims to document the diversity in leaf pheno-phases in terms of duration of deciduousness (which is reciprocal to growing season length), wood density, leaf mass per area (LMA) and leaf strategy index in 24 important tree species growing in the Vindhyan dry tropical forest in India.

- On the basis of phenological observations, the tree species were categorized into two main groups: leaf exchanging species exhibiting overlapping periods of leaf fall and leaf flush, and deciduous species whose timings of leaf flush and leaf fall differ resulting in a time lag (deciduousness) between the completion of leaf fall and initiation of leaf flush. Presence of wide range of deciduousness duration (from ca. a week to 7 months) among dry tropical trees indicates large variations in their growing season length. In the tree species studied, as the duration of deciduousness increased, leaf flushing period decreased significantly but leaf fall period showed little variation.

- Differing deciduousness in tree species exhibited substantial differences in their leafing (vegetative growth) pattern, as reflected by ratio of durations of leaf flush to leaf fall (leaf strategy index). Across different species, duration of deciduousness was significantly positively correlated with leaf strategy index, and significantly negatively correlated with both wood density and LMA.

- Wide variations in deciduousness, leaf strategy index, wood density and LMA in the 24 species investigated indicate considerable functional diversity in tree species growing in Vindhyan dry tropical region. Variation in seasonal duration of deciduousness among species is reflections of differences in tree functional traits like stem wood density, leaf strategy index and LMA.
\end{abstract}

Résumé - La diversité des défoliations et les traits phénologiques d'arbres clés de la forêt sèche tropicale indienne.

- Dans les forêts sèches tropicales saisonnières, la défoliation est une stratégie importante des arbres pour survivre dans les périodes de stress hydrique durant l'été. La défoliation est un reflet de l'interaction entre la sécheresse saisonnière, les caractéristiques des arbres et les conditions d'humidité du sol.

- La présente étude vise à documenter la diversité des phénophases des feuilles en termes, de durée de la défoliation (qui est réciproque à la durée de la saison de croissance), de densité du bois, de masse foliaire par unité de surface (LMA) et d'indice de stratégie des feuilles chez 24 importantes espèces d'arbres poussant dans la forêt sèche tropicale de Vindhyan en Inde.

- Sur la base d'observations phénologiques, les espèces d'arbres ont été classées en deux groupes principaux : espèces présentant des périodes de chevauchement de la chute des feuilles et de la feuillaison et espèces décidues dont les rythmes de feuillaison et de chute des feuilles diffèrent d'où un décalage dans le temps entre la fin de la chute des feuilles et l'initiation de la feuillaison.

\footnotetext{
*Corresponding author: kushwahacp@yahoo.com
} 
La présence d'une large variation de la durée de défoliation (environ d'une semaine à 7 mois) parmi les arbres tropicaux secs indique de grandes variations dans la longueur de leur saison de croissance. Chez les espèces d'arbres étudiées, comme la durée de défoliation augmente, la période de feuillaison diminue significativement, mais la période de chute des feuilles montre peu de variations.

- Différentes défoliation chez les espèces ont montré des différences importantes dans leur modèle de croissance végétative, comme en témoignent les taux des durées de feuillaison par rapport à la chute des feuilles (indice de stratégie de la feuille). A travers les différentes espèces, la durée de défoliationétait significativement positivement corrélée avec l'indice de stratégie de la feuille, et significativement corrélée négativement avec la densité du bois et LMA.

- Des écarts importants de défoliation, d'indice de stratégie de la feuille, de densité du bois et LMA, chez les 24 espèces étudiées montrent une diversité fonctionnelle considérable chez les espèces poussant dans la région tropicale sèche de Vindhyan. Les variations saisonnières entre espèces de la durée de défoliation sont les reflets de différences dans des caractéristiques fonctionnelles comme la densité du bois des tiges, l'indice de stratégie de feuilles et LMA.

\section{INTRODUCTION}

Seasonally dry tropical forest vegetation is comprised of multitude of tree species exhibiting differing drought adaptation and duration of deciduousness or leaflessness (Borchert et al., 2002; Singh and Kushwaha, 2005a). Deciduousness is a water conservation strategy of trees to overcome dry season water stress, an aspect often understated in phenological studies in dry tropics. In Indian dry tropical forest trees the duration of deciduousness (characterized by $100 \%$ reduction in assimilation rate) varies widely from being almost non-existent in semi-evergreen species to extending more than six months in several species (Kushwaha and Singh, 2005). Thus, leaf phenology may be viewed from the broader perspective of a gradient of variation in the duration of deciduousness across tree species. Despite the recognized significance of tree deciduousness in forest classification and ecosystem functions, quantitative estimates of duration of deciduousness (i.e. time lag between completion of leaf fall and initiation of leaf flushing, which is reciprocal to growing season length) in tropical forests are highly limited (Kushwaha and Singh, 2008; Singh and Kushwaha, 2005a). Due to high sensitivity of trees to changes in climatic conditions (De Bie et al., 1998; Yoshifuji et al., 2006) prediction of the impact of climate change on the annual duration of deciduousness is a major challenge in ecology of dry tropics (Do et al., 2005).

Differences in tree leaves and wood density, arising from phylogeny and adaptations, are helpful for species coexistence (King et al., 2006; Kitajima and Poorter, 2008). As a result of interaction with soil water availability and stem water status, leaf traits and stem wood density strongly affect phenology and distribution of species (Borchert et al., 2002). Leaf mass per area (LMA), an important leaf pheno-trait related to carbon economy, is a structural variable which plays a significant role in effecting inter-specific variation in relative growth rate (Garnier, 1992). LMA has been found to be positively related to leaf life span and negatively to photosynthetic rate per leaf mass (Wright et al., 2004). In terms of drought adaptations, high LMA tends to increase water use efficiency (Davi et al., 2008). Compared to evergreen and/or leaf exchanging species, the deciduous tree species generally exhibit lower LMA and leaf thickness (Prior et al., 2003).
Integrating the effect of many years of environmental conditions, wood density affects the physiological performance of leaf and the whole-plant, and seems determined by water uptake and the ability to access soil water during dry season (Bucci et al., 2004). Tropical trees show enormous variation in wood density (from 0.11 to $0.92 \mathrm{~g} \mathrm{~cm}^{-3}$ ) compared to temperate trees $\left(0.31\right.$ to $\left.0.66 \mathrm{~g} \mathrm{~cm}^{-3}\right)$ and such variation bears important consequences for the dimensions and architecture of their perennial stems (Poorter, 2008). Wood density along with LMA and resource use (photosynthesis) rate may significantly relate to the extent of deciduousness (which is reciprocal to leaf longevity) in tropical trees because all these characteristics are closely related to leaf longevity (Reich et al., 1997). Due to increased stem wood density and LMA, tree species tend to have longer average leaf life span and slower growth rate (Reich et al., 1992; Wright et al., 2005).

Tree species in seasonally dry tropical forests often show differing ratios of duration of leaf flush/duration of leaf fall (leaf strategy index proposed by Kushwaha and Singh, 2005). Leaf strategy primarily denotes the adaptations in leaf dynamics controlling the ability of a tree species to exploit/utilize resources (e.g. water, nutrients, $\mathrm{CO}_{2}$ ) in relation to its ability to conserve the same (Singh and Kushwaha, 2005a). While the magnitude of resource utilization may be related with duration and number/mass of leaves produced, the durations of leaf fall and deciduousness have a bearing on resource conservation.

In tropical dry forests, which represent ca. $40 \%$ of the total forested land in India, information on leaf phenological diversity in terms of duration of deciduousness and tree characteristics like wood density and LMA is highly limited. There is need to precisely quantify the seasonal onset and duration of deciduousness and other related phenological traits in different tree species. The present study tested the hypothesis that variation in deciduousness duration across tree species is a reflection of differences in traits like stem wood density, leaf strategy index and LMA. This study, carried out in Indian tropical dry deciduous forest, addresses the following questions: (1) What is the diversity among tree species in terms of leafing and deciduousness (leafless) periods? (2) What are the relationships among LMA, leaf strategy index, stem wood density, and the duration of deciduousness? 

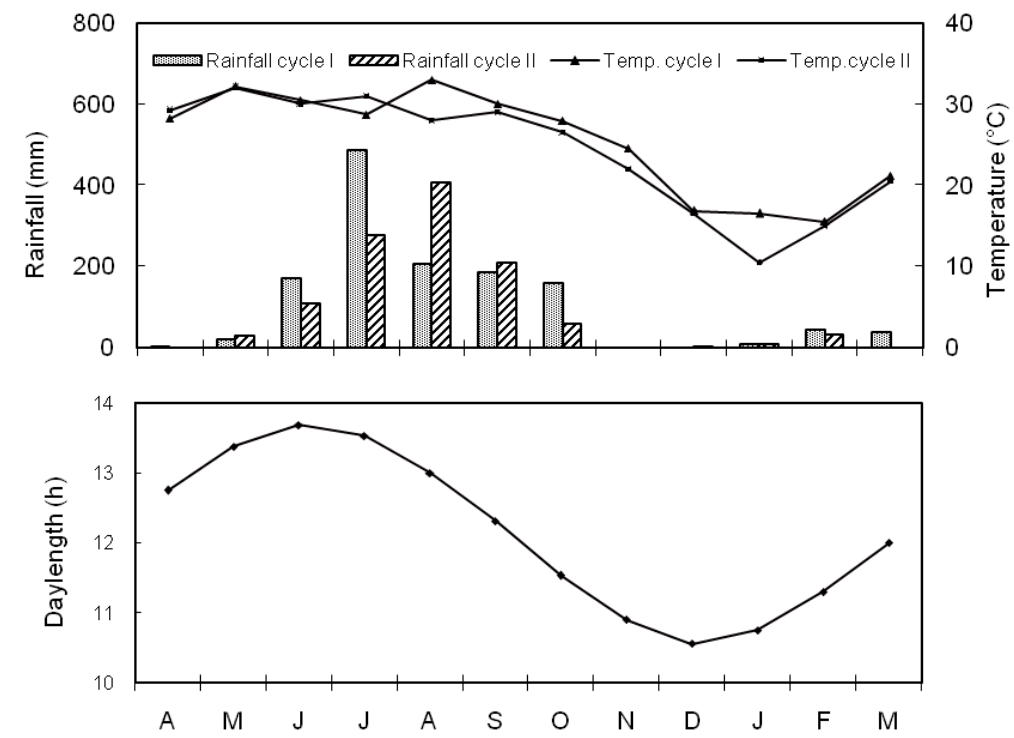

Figure 1. Seasonal variation in rainfall, temperature and day length during the study period in Vindhyan tropical deciduous forest area, India.

\section{MATERIALS AND METHODS}

\subsection{Study site}

The present study was carried out in the Hathinala Forest (24 $18^{\prime} \mathrm{N}, 83^{\circ} 6^{\prime} \mathrm{E}$; elevation, 315-485 $\mathrm{m}$ a.s.1.), which is spread over the Vindhyan plateau (ca. $150 \mathrm{~km}$ away from Varanasi), in the Sonbhadra district of Uttar Pradesh, India. The study site represents the least-disturbed forest stand in the region. At Hathinala, several low hills rising 20 to $40 \mathrm{~m}$ above the general terrain, undulating ridge top and plateau are widespread resulting in heterogeneous landscape marked by a mosaic of differing microsites, ranging from nutrient and water rich depressions to exposed dry shallow soil ridges/hills.

In the Hathinala forest (Northern Tropical Dry Deciduous Forest type, subgroup 5-B of Champion and Seth, 1968) the top-storey trees form nearly continuous $15-20 \mathrm{~m}$ high canopy, underlain by a discontinuous lower storey of trees. While leaf exchanging species are mostly distributed in relatively moist sites at hill bases, species remaining deciduous for long intervals are generally restricted to ridges/hill tops. Majority of other deciduous species are distributed widely from moist to dry microsites.

The climate is characterized by three seasons: warm-wet rainy (mid June-September); cool-dry winter (November-February); and hot-dry summer (April-June). October and March represent the transition months between seasons, the major part of both being closer to the season following them. The mean monthly maximum (day) temperature varies from $20{ }^{\circ} \mathrm{C}$ in January to $42{ }^{\circ} \mathrm{C}$ in May, and the mean minimum (night) temperature from $10{ }^{\circ} \mathrm{C}$ in January to $24^{\circ} \mathrm{C}$ in May (Fig. 1). About $85 \%$ of the annual rainfall occurs during the rainy season from the south-west monsoon, and 7-8 dry months occur during the annual cycle. During the two annual cycles the total rainfall was: $1318 \mathrm{~mm}, 1125 \mathrm{~mm}$. Long-term annual rainfall varies between 850 to $1300 \mathrm{~mm}$.

\subsection{Experimental design}

To document the patterns of leaf phenological diversity five adult individuals $(>30 \mathrm{~cm} \mathrm{GBH}$ ) of each species listed in Table I were marked at Hathinala site. On each marked individual, four twigs (currently growing shoots of last-order branches) on each of four major branches (one in each direction) were marked with metal tags. Thus, for each species 80 twigs were selected to represent the whole plant canopy. On these twigs monthly observation of phenological events was made from April 2006 to May 2008. Based on previous experience (Kushwaha and Singh, 2005; Singh and Kushwaha, 2006), observations during the intense phenological period was made at $15 \mathrm{~d}$ interval.

The following phenological events were derived from periodical observations of marked individuals: initiation of leaf flush, completion of leaf flush, leaf-fall initiation, and completion of leaf fall. Leaf flush period of a species is the duration (days) from the first leaf flush to the last flush amongst its individuals. Similarly, leaf fall period of a species represents the time duration from the estimated first leaf fall to the last amongst individuals. For each individual of a species leaf-flush and leaf-fall periods were calculated to range $7.5 \mathrm{~d}$ before and after the date on which the event was recorded for the first and the last time. The deciduousness duration (leafless period) for each species was calculated as the mean leafless duration of individuals. Leaf strategy index (ratio of leaf-flush rate to leaf-fall rate, Kushwaha and Singh, 2005) for each species was calculated in this study as the ratio of leaf fall duration to leaf flush duration (mean of 5 individuals), assuming that equal number of leaves participate in both events during the annual cycle.

For the estimation of sapwood density three individuals of each species were randomly selected, and three stem cores per individual (total nine cores per species) were taken during March-April. Samples were taken with an increment borer, sealed in aluminum foil and plastic bags, and were taken to the laboratory. Bark was removed from each core and then cores were placed in water in a small graduated cylinder to determine the volume. The cores were oven-dried $\left(80^{\circ} \mathrm{C}\right)$ to a constant mass and weighed to obtain the dry mass. Wood density was determined by dividing the dry mass by the volume of the sample. For the estimation of leaf mass per area (LMA) 125 mature leaves from the whole crown of five selected individuals (25 leaves per individual) of each species were collected during SeptemberOctober. Four leaf discs of $1 \mathrm{~cm}^{2}$ were taken (one each from upper 
Table I. Variations in wood density, leaf mass per area (LMA), durations of leaf flush and leaf fall, leaf strategy index and extent of deciduousness in tree species in Vindhyan dry forest in India; values are mean $\pm \mathrm{SE}$.

\begin{tabular}{|c|c|c|c|c|c|c|}
\hline \multirow[t]{2}{*}{ Species } & \multirow[t]{2}{*}{$\begin{array}{l}\text { Wood density } \\
\qquad\left(\mathrm{g} \mathrm{cm}^{-3}\right)\end{array}$} & \multirow[t]{2}{*}{$\begin{array}{c}\text { LMA } \\
\left(\mathrm{g} \mathrm{m}^{-2}\right)\end{array}$} & $\begin{array}{l}\text { Leaf } \\
\text { flush }\end{array}$ & $\begin{array}{c}\text { Leaf } \\
\text { fall }\end{array}$ & \multirow{2}{*}{$\begin{array}{c}\text { Leaf } \\
\text { strategy } \\
\text { index } \\
\end{array}$} & \multirow{2}{*}{$\begin{array}{c}\text { Deciduousness } \\
\text { duration } \\
\text { (days) }\end{array}$} \\
\hline & & & \multicolumn{2}{|c|}{ Duration (days) } & & \\
\hline \multicolumn{7}{|l|}{ Leaf-exchanging } \\
\hline Albizia odoratissima (L. f.) Benth. & $0.625 \pm 0.015$ & $108.7 \pm 1.0$ & $188 \pm 6$ & $86 \pm 2$ & $0.46 \pm 0.015$ & $7 \pm 3$ \\
\hline Bauhinia racemosa Lamk. & $0.667 \pm 0.013$ & $119.0 \pm 1.1$ & $159 \pm 5$ & $71 \pm 2$ & $0.44 \pm 0.013$ & $3 \pm 1$ \\
\hline Shorea robusta C.F. Gaertn. & $0.718 \pm 0.011$ & $112.7 \pm 1.2$ & $180 \pm 4$ & $80 \pm 3$ & $0.44 \pm 0.015$ & $9 \pm 3$ \\
\hline $\begin{array}{l}\text { Soymida febrifuga (Roxb.) A. Juss. } \\
<2 \text {-month deciduous }\end{array}$ & $0.859 \pm 0.021$ & $140.2 \pm 0.2$ & $171 \pm 3$ & $80 \pm 2$ & $0.46 \pm 0.004$ & $6 \pm 3$ \\
\hline Anogeissus latifolia (Roxb. Ex DC) Wall. ex Bedd. & $0.801 \pm 0.008$ & $136.0 \pm 0.9$ & $125 \pm 3$ & $77 \pm 2$ & $0.61 \pm 0.005$ & $52 \pm 5$ \\
\hline Buchanania lanzan Spreng. & $0.458 \pm 0.006$ & $97.6 \pm 0.8$ & $117 \pm 2$ & $75 \pm 2$ & $0.64 \pm 0.011$ & $47 \pm 6$ \\
\hline Cassia fistula $\mathrm{L}$. & $0.735 \pm 0.018$ & $92.7 \pm 0.5$ & $122 \pm 1$ & $74 \pm 1$ & $0.60 \pm 0.005$ & $46 \pm 4$ \\
\hline Diospyros melanoxylon Roxb. & $0.685 \pm 0.013$ & $124.0 \pm 0.9$ & $120 \pm 5$ & $81 \pm 3$ & $0.68 \pm 0.018$ & $46 \pm 3$ \\
\hline Elaeodendron glaucum Pers. & $0.666 \pm 0.018$ & $109.8 \pm 0.6$ & $116 \pm 4$ & $74 \pm 3$ & $0.64 \pm 0.004$ & $56 \pm 4$ \\
\hline Hardwickia binata Roxb. & $0.727 \pm 0.015$ & $109.9 \pm 0.7$ & $122 \pm 3$ & $83 \pm 3$ & $0.68 \pm 0.021$ & $30 \pm 4$ \\
\hline Ougeinia oogeinsis (Roxb.) Hochr. & $0.705 \pm 0.005$ & $116.5 \pm 0.7$ & $125 \pm 3$ & $77 \pm 2$ & $0.61 \pm 0.012$ & $42 \pm 2$ \\
\hline Terminalia chebula Retz. & $0.642 \pm 0.009$ & $102.2 \pm 0.6$ & $126 \pm 3$ & $77 \pm 2$ & $0.60 \pm 0.006$ & $53 \pm 5$ \\
\hline \multicolumn{7}{|l|}{ 2-4-month deciduous } \\
\hline Acacia catechu (L. f.) Willd. & $0.889 \pm 0.008$ & $120.4 \pm 0.7$ & $98 \pm 5$ & $87 \pm 3$ & $0.89 \pm 0.020$ & $93 \pm 2$ \\
\hline Flacourtia indica (Burm. f.) Merr. & $0.616 \pm 0.009$ & $101.4 \pm 1.1$ & $97 \pm 3$ & $86 \pm 4$ & $0.88 \pm 0.028$ & $116 \pm 5$ \\
\hline Gardenia turgida Roxb. & $0.645 \pm 0.027$ & $99.4 \pm 0.7$ & $98 \pm 5$ & $84 \pm 4$ & $0.86 \pm 0.006$ & $75 \pm 3$ \\
\hline Lagerstroemia parviflora Roxb. & $0.617 \pm 0.010$ & $112.3 \pm 0.8$ & $103 \pm 5$ & $84 \pm 4$ & $0.81 \pm 0.007$ & $83 \pm 8$ \\
\hline Miliusa tomentosa (Roxb.) Sinclair & $0.626 \pm 0.009$ & $97.7 \pm 0.8$ & $96 \pm 4$ & $81 \pm 4$ & $0.84 \pm 0.014$ & $102 \pm 3$ \\
\hline $\begin{array}{l}\text { Terminalia tomentosa Wt. \&Arn. } \\
>\text { 4-month-deciduous }\end{array}$ & $0.653 \pm 0.025$ & $102.0 \pm 1.2$ & $99 \pm 2$ & $80 \pm 2$ & $0.80 \pm 0.003$ & $86 \pm 5$ \\
\hline Adina cordifolia (Roxb.) Hook. f. ex Brandis & $0.575 \pm 0.005$ & $90.8 \pm 0.7$ & $74 \pm 3$ & $74 \pm 3$ & $1.00 \pm 0.005$ & $129 \pm 3$ \\
\hline Bombax ceiba $\mathrm{L}$ & $0.335 \pm 0.007$ & $81.0 \pm 0.9$ & $62 \pm 2$ & $62 \pm 2$ & $1.00 \pm 0.006$ & $152 \pm 3$ \\
\hline Boswellia serrata Roxb. cx Colebr. & $0.505 \pm 0.008$ & $85.4 \pm 0.6$ & $69 \pm 2$ & $68 \pm 2$ & $0.98 \pm 0.003$ & $144 \pm 4$ \\
\hline Chloroxylon swietenia DC. & $0.773 \pm 0.018$ & $99.7 \pm 0.9$ & $66 \pm 3$ & $65 \pm 3$ & $0.98 \pm 0.003$ & $136 \pm 2$ \\
\hline Lannea coromandelica (Houtt.) Merrill & $0.509 \pm 0.016$ & $86.0 \pm 0.7$ & $62 \pm 2$ & $60 \pm 2$ & $0.98 \pm 0.003$ & $231 \pm 8$ \\
\hline Sterculia urens Roxb. & $0.411 \pm 0.007$ & $74.9 \pm 1.2$ & $62 \pm 2$ & $59 \pm 1$ & $0.96 \pm 0.010$ & $224 \pm 4$ \\
\hline
\end{tabular}

and lower part of mid rib and two from both side of mid rib). Thus, for each species 500 discs were collected. Oven dry $\left(80^{\circ} \mathrm{C}\right)$ weight of leaf per unit area is reported as LMA. In case of Acacia catechu, dry mass and area of leaflets were determined and converted to dry mass per unit area.

\subsection{Statistical analysis}

Relationships among duration of deciduousness, leaf strategy index, LMA, and wood density across different species were examined with the help of SPSS package on a PC by computing correlation coefficients using species mean values.

\section{RESULTS}

Among total 24 species studied, four species were leaf exchanging semi-evergreen and the remaining showed variable extent of deciduousness (Fig. 2). Deciduous species showed temporally separated single leaf-flush (new leaf formation) and leaf-fall periods, and leaf flush always began on completely leafless twigs. In leaf exchanging species during the overlap of leaf-flush and leaf-fall, new leaves (lush green) and old leaves (yellowish green) were easily differentiated. Out of the four leaf-exchanging semi-evergreen species studied, Albizia odoratissima, Bauhinia racemosa and Shorea robusta showed leaf exchange (overlapping periods of leaf fall and leaf flush) in March, and Soymida febrifuga did the same in April-May. In leaf exchanging species leaf fall occurred between December and April and leaf flush between March and mid-September. Deciduous species, on the other hand, differed dramatically with respect to the timings of leaf flushing and leaf fall, showing widely varying timings and durations of deciduousness. Amongst deciduous species, ca. $15 \%$ species (Terminalia chebula, Flacourtia indica and Ougeinia oogeinsis) initiated leaf flushing in April, majority ca. 55\% species (Anogeissus latifolia, Buchanania lanzan, Diospyros melanoxylon, 


\begin{tabular}{|c|c|c|c|c|c|c|c|c|c|c|c|}
\hline & & Leaf $F$ & lush & & & $\mathrm{Ma}$ & ure I & & & Leaf fall & Leafless \\
\hline Species & Family & \begin{tabular}{l|l|}
$\mathbf{A}$ & $\mathbf{M}$ \\
\end{tabular} & $\mathbf{J}$ & $\mathbf{J}$ & A & $\mathbf{S}$ & 0 & $\mathbf{N}$ & D & \begin{tabular}{l|l|l}
$\mathbf{J}$ & $\mathbf{F}$ & $\mathbf{M}$ \\
\end{tabular} & \begin{tabular}{l|l|}
$\mathbf{M}$ & $\mathrm{J}$ \\
\end{tabular} \\
\hline Leaf-exchanging & & & & & & & & & & & \\
\hline Albizia odoratissima & Mimosaceae & & & & & & Cycle 1 & & & & \\
\hline & & & & & & & Cycle & & & & \\
\hline Bauhinia racemosa & Caesalpiniaceae & & & & & & & & & & \\
\hline & & & & & & & & & & & \\
\hline Shorea robusta & Dipterocarpaceae & & & & & & & & & & \\
\hline Soymida febrifuga & & & & & & & & & & & [ \\
\hline soymida rebriruga & Millaceae & & & & & & & & & & \\
\hline$<2$-month deciduous & & & & & & & & & & & \\
\hline Anogeissus latifolia & Combretaceae & HIIIIIII & & & & & & & & & HI \\
\hline Buchanania lanzan & Anacardiaceae & HIII & & & & & & & & & IIII \\
\hline & & ifitii & & & & & & & & & IIIII \\
\hline Cassia fistula & Caesalpiniaceae & HI & & & & & & & & & 111 \\
\hline & & IIIIIIIIIIII - - - & & & & & & & & & IIII \\
\hline Diospyros melanoxylon & Ebenaceae & Hit & & & & & & & & & HIII \\
\hline Elaeodendron glaucum & Celastraceae & HH & & & & & & & & & HH \\
\hline & & IIIIII & & & & & & & & & IIIIII \\
\hline Hardwickia binata & Caesalpiniaceae & Hit & & & & & & & & & Hi \\
\hline Ougeinia oogeinsis & Fabaceae & & & & & & & & & II & 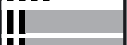 \\
\hline & & III & & & & & & & & & \\
\hline Terminalia chebula & Combretaceae & & & - & & & & & & & \\
\hline 2-4 month deciduous & & & & & & & & & & & \\
\hline Acacia catechu & Mimosaceae & HHH & & & & & & & & & HIIII \\
\hline Flacourtia indica & Flacourtiaceae & & & $=$ & & & & & & |l|IIII & \\
\hline & & & & 工 & & & & & & & \\
\hline Gardenia turgida & Rubiaceae & HH & & & & & & & & & HH \\
\hline & & IIIIII & & & & & & & & & |IIII| \\
\hline Lagerstroemia parviflora & Lythraceae & HIIIII & & & & & & & & & HIIII \\
\hline Miliusa tomentosa & Annonaceae & III & & & & & & & & HIIII & III \\
\hline Terminalia tomentosa & Combretaceae & IIIIIIIII & & & & & & & & & |IIIIIII \\
\hline & & Hith & & & & & & & & & \\
\hline$>4$ month deciduous & & & & & & & & & & & \\
\hline Adina cordifolia & Rubiaceae & HAH & & & & & & & & & HIIIIIIIIIII \\
\hline Bombax ceiba & Bombacaceae & IIII & & $=$ & & & & & & HIIIII & HII \\
\hline Boswellia serrata & Burseraceae & |IIIIIIII & & & & & & & & |||||||||| & |IIIII \\
\hline & & IIIIII & & & & & & & & & \\
\hline Chloroxylon swietenia & Rutaceae & HHH & & & & & & & & IIIIIII & HIII \\
\hline & & & & & & & & & & & \\
\hline Lannea coromandelica & Anacardiaceae & HIII & & $=$ & & & & & & HIIII & IIII \\
\hline Sterculia urens & Sterculiaceae & IIIII & & & & & & & III & IIIIIIII & IIIIII \\
\hline
\end{tabular}

Figure 2. Diversity in seasonal patterns of leaf flush, mature leaf period, leaf fall and deciduousness (leaflessness) duration in key tree species as observed during two consecutive annual cycles in the Vindhyan tropical deciduous forest; April, May and June values have been shown twice for clarity.

Elaeodendron glaucum, Hardwickia binata, Gardenia turgida, Lagerstroemia parviflora, Miliusa tomentosa, Bombax ceiba and Lannea coromendelica) began leaf flushing in May, and the remaining ca. $30 \%$ species (Acacia catechu, Adina cordifolia, Terminalia tomentosa, Boswellia serrata, Chloroxylon swietenia, and Sterculia urens) did so in June.

Although leaf flushing was initiated between April and June, among deciduous species the timings of leaf fall varied considerably (Fig. 2): < 2-month-deciduous species showed leaf fall between December and March; 2-4-month-deciduous species showed leaf fall between October and mid-March; and > 4-month-deciduous species showed leaf fall between September and mid-February. It is evident that across the tree species studied increase in the annual duration of deciduousness is associated with earliness of leaf fall (i.e. fall shifting towards the end of rainy season) without any marked change in the duration of leaf fall, and delayed leaf flush (i.e. closer to the onset of rainy season) with sharp decrease in flush duration.

With increase in deciduousness duration in different species their leaf flushing period decreased significantly; $159-188 \mathrm{~d}$ in 
leaf-exchanging species, 116-126 $\mathrm{d}$ in $<2$-month-deciduous species, 96-103 d in 2-4-month-deciduous species, and $62-74 \mathrm{~d}$ in $>4$-month-deciduous species (Tab. I). In contrast, leaf fall period in all species ranged between 59 and $87 \mathrm{~d}$; however leaf fall timing amongst species varied markedly. Leaf strategy index increased as a function of deciduousness duration; it ranged from $0.44-0.46$ for leaf exchanging species, 0.60-0.68 for < 2-month-deciduous species, 0.80-0.89 for 2-4-month-deciduous species, and 0.96-1.00 for $>4$-monthdeciduous species. Species having leaf strategy index $<0.5$ show semi-evergreenness (leaf-exchange), and as the duration of deciduousness increases, the index proportionately increases above 0.5 .

Generally, stem wood density decreased with increase in the duration of deciduousness of species (Tab. I). LMA was maximum for leaf-exchanging species followed by $<2$-month-deciduous, 2-4-month-deciduous, and $>4$-month-deciduous species. Higher wood density and LMA were recorded in < 2-month-deciduous Anogeissus latifolia, 2-4-month-deciduous Acacia catechu, and > 4-monthdeciduous Chloroxylon swietenia compared to other species in their respective groups. Estimated mean duration of deciduousness ranged 3-9 d in leaf-exchanging species, 30-56 d in < 2-month-deciduous species, 75-116 d in 2-4-monthdeciduous species, and 129-231 d in > 4-month-deciduous species.

Relationships among duration of deciduousness (leafless period), leaf strategy index, LMA, and wood density were examined across different species (Fig. 3). Deciduousness duration was significantly positively correlated with leaf strategy index $(r=0.89, p<0.01, n=24)$, and significantly negatively correlated with stem wood density $(r=-0.58, p<0.01$, $n=24)$ and with LMA $(r=-0.73, p<0.01, n=24)$. Across species, leaf strategy index showed significant negative correlation with LMA $(r=-0.66, p<0.01, n=24)$ and with wood density $(r=-0.46, p<0.05, n=24)$. LMA and wood density were positively correlated $(r=0.79, p<0.01, n=24)$.

\section{DISCUSSION}

In the present study episodic leaf flush (denoting termination of deciduousness) and leaf fall (initiation of deciduousness) with variable timings in both leaf-exchanging and deciduous species result in marked annual periodicity in these events that leads to considerable diversity among species in terms of timing of leaf pheno-phases. Initiation of leaf flush in majority of species during the dry period and onset of leaf fall at different times after the end of rainy season in our study may be related to varying adaptations of tree species to seasonal moisture availability. Leaf senescence being an evolutionarily acquired process, the variation in timing and patterns of leaf fall among phenological functional types may be result of their adaptations to microhabitats varying in levels of soil moisture (Lim et al., 2007). The wide range of duration of deciduousness recorded in our study indicates considerable inter-species variation in terms of period of inactivity, or conversely in terms of the growing season length (being inversely proportional to duration of deciduousness). Wide range of deciduousness duration has been reported in other dry tropical regions: 1-3.5 months in Venezuela (Olivares and Medina, 1992); < 1-4 months in Thailand (Rivera et al., 2002); up to 8 months in West Africa (De Bie et al., 1998). Huge variations in deciduousness duration occur even in conspecific individuals of many tropical tree species due to differences in site conditions (De Bie et al., 1998; Singh and Kushwaha, 2005b). Such inter- and intra-species variations in deciduousness may be related to high sensitivity of tropical trees to even small changes in site conditions, especially the degree of water stress experienced by them. More than 4-month-deciduous waterstoring tree species, showing low wood density and low LMA, initiate leaf fall just after the cessation of rains (during early dry season) and complete it within a short period, reflecting an adaptive strategy to restrict the loss of large amount of water stored in their light wood stems. Other deciduous species ( $<2$-month-deciduous and 2-4-month deciduous), with relatively higher wood density and LMA, maintain their leaves further into the dry season possibly due to greater ability of these species to tolerate negative tree water potentials (Choat et al., 2005). Replacement of old leaves with new in the mid dry season in leaf-exchanging species may be a water conservation strategy to face the seasonal drought condition.

In tropical trees initiation of leaf flush (vegetative bud break), marking the termination of deciduousness duration, has been reported to be triggered by several factors (e.g. shedding of old leaves, increasing day length and/or temperature, and significant amount of first rain; Rivera et al., 2002; Singh and Kushwaha, 2005a). Occurrence of leaf flush during middry season in leaf-exchanging species studied presently suggests role of shedding of old leaves in triggering leaf flush. In contrast, largely synchronous leaf flush initiation in deciduous species during hot-dry summer or early rainy season (Fig. 2) may indicate the joint action of increasing day length and temperature in leaf flush initiation. In few species vegetative buds break during June (after the first significant rain of rainy season) indicates the predominant role of rains in leaf flushing. Rapid rehydration due to rains results in synchronous buds break in trees (Borchert et al., 2004). Occurrence of leaf flushing during the dry season (well before the onset of rainy season) in leaf-exchanging and majority of deciduous species may also be an adaptation to reduce the herbivorous insect attack. The new leaf stage is considered most vulnerable stage of development for insect attack which intensifies greatly after rain onset.

There is a great potential in dry tropical trees to survive in stress condition by acquiring a range of strategies that depend on an organism's ability to store/access water. It can be argued that in > 4-month-deciduous tree species (having low wood density and lower LMA), usually growing on relatively drier sites, both leaf flush and leaf fall are rapid, both completed within short periods, adjusting to short availability of growing conditions (during rainy season). We suggest that these tree species showing short in-leaf period or long deciduousness period are stress-intolerent. The shortcoming of reduced in-leaf period may be compensated by their ability to exploit resources at a rapid rate. On the other hand, leaf-exchanging 

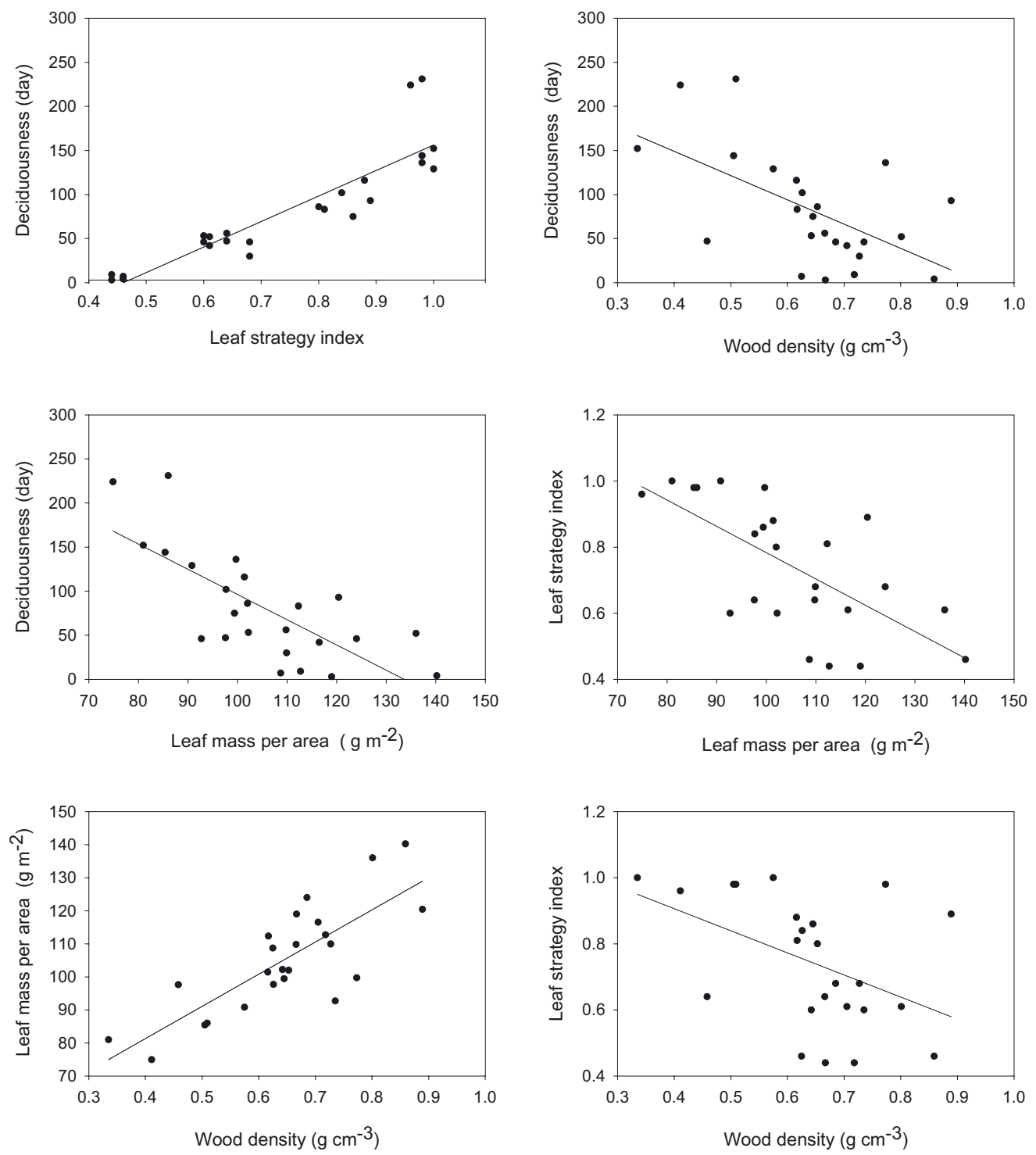

Figure 3. Relationships among deciduousness duration, leaf mass per area, leaf strategy index (ratio of duration of leaf fall to duration of leaf flush), and stem wood density of key tree species in Vindhyan tropical deciduous forest.

species (having higher wood density and greater LMA), growing in relatively moist sites, show much longer leaf flush and in-leaf periods (hence almost obliterated deciduousness duration) exploiting resources for much longer period, possibly at a slower rate, the leaf exchanging species appear to stresstolerant. The longevity of leaves is closely associated with environmental resource availability (e.g. light, nutrient, water) and the growth strategy of the species (Seiwa et al., 2005). In the presently studied species, onset of early leaf fall (with almost constant duration) and delayed leaf flush (closer to the onset of rainy season) with sharp decrease in flush duration as a result of increased annual deciduousness duration may be a reflection of varying resource use rates.

Differences in LMA, reported to be associated with variations in leaf phenology, are caused by environmental factors (Prior et al., 2003). Significant relationships of LMA and wood density with leaf strategy index and with the extent of deciduousness, noticed in our study, suggest their significant role during both growth and deciduousness periods. Species with high LMA tend to have long average leaf life span and slow photosynthetic rates (Field and Mooney, 1986; Niinemets, 1999). Mass based assimilation decreases with increasing leaf life span (which is reciprocal to deciduousness duration, as in our study) and LMA (Prior et al., 2003; Reich et al., 1992). Decrease in LMA is associated with increased water content resulting in small fraction of dry matter (Roderick, 2000). Significant decrease in LMA with increase in deciduousness duration suggests that with increasing deciduousness leaves tend to contain more water content and less dry matter per unit area.

Presently studied tropical dry forest reveals high functional diversity in tree species, reflected by the extent of deciduousness, leaf strategy index, wood density and LMA. Duration 
of deciduousness, the most reliable indicator of the severe drought experienced by different species, reflects the integrated effect of seasonal drought, tree characteristics and soil moisture condition. Longer dry season (conversely shorter wet season), large inter-annual variations in precipitation and rise in temperature predicted for the tropical forest zone including India (Hulme and Viner, 1998) are likely to alter the length of deciduousness (and hence the growing season) by affecting timings of leaf flush and leaf fall. Thus, when worldwide emphasis is on increasing growing season length of temperate deciduous forests, tropical deciduous forests deserve special consideration because of their greater geographical area, high functional diversity and high degree of anthropogenic disturbance, and their unclear responses to the impending climate change.

Acknowledgements: The authors are grateful to the Head and Coordinator, Centre of Advanced Study in Botany, and the Coordinator, Centre for Environmental Science \& Technology, Banaras Hindu University for facilities. Financial support was provided to CPK by the Department of Science and Technology, Government of India (under Fast Track Young Scientist Scheme) and Council of Scientific and Industrial Research, New Delhi (under Scientist Pool Scheme).

\section{REFERENCES}

Borchert R., Meyer S.A., Felger R.S., and Porter-Bolland L., 2004. Environmental control of flowering periodicity in Costa Rican and Mexican tropical dry forests. Glob. Ecol. Biogeogr. 13: 409-425.

Borchert R., Rivera G., and Hagnauer W., 2002. Modification of vegetative phenology in a tropical semi-deciduous forest by abnormal drought and rain. Biotropica 34: 27-39.

Bucci S.J., Goldstein G., Meinzer F.C., Scholz F.G., Franco A.C., and Bustamante M., 2004. Functional convergence in hydraulic architecture and water relations of tropical savanna trees: from leaf to whole plant. Tree Physiol. 24: 891-899.

Champion H.G. and Seth S.K., 1968. A Revised survey of the forest types of India. Manager of Publications, Government of India, New Delhi.

Choat B., Ball M.C., Luly J.G., and Holtum J.A.M., 2005. Hydraulic architecture of dry rain forest trees from North Queensland, Australia. Trees 19: 305-311.

Davi H., Barbaroux C., Dufrene E., Francois C., Mantpied P., Breda N., and Badeck F., 2008. Modeling leaf mass per area in forest canopy as affected by prevailing radiation conditions. Ecol. Model. 211: 339_ 349.

De Bie S., Ketner P., Paase M., and Geerling C., 1998. Woody plant phenology in the West African savanna. J. Biogeogr. 25: 883-900.

Do F.C., Goudiaby V.A., Gimenez O., Diagne A.L., Diouf M., Rocheteau A., and Akpo L.E., 2005. Environmental influence on canopy phenology in the dry tropics. For. Ecol. Manage. 215: 319-328.

Field C. and Mooney H.A., 1986. The photosynthesis-nitrogen relationship in wild plants. In: Givnish T.J. (Ed.), On the economy of plant form and function, Cambridge University Press, Cambridge, pp. $25-55$.

Garnier E., 1992. Growth analysis of congeneric annual and perennial grass species. J. Ecol. 80: 665-675.

Hulme A. and Viner D., 1998. A climate change scenario for the tropics. Clim. Change 39: 145-176.
King D.A., Davies S.J., Tan S., and Boor N.S.M., 2006. The role of wood density and stem support costs in the growth and mortality of tropical trees. J. Ecol. 94: 670-680.

Kitajima K. and Poorter L., 2008. Functional basis for resource niche differentiation by tropical trees. In: Carson W.P., Schnitzer S.A. (Eds.), Tropical forest community ecology, Oxford, Blackwell Publishing, pp. $160-181$.

Kushwaha C.P. and Singh K.P., 2008. India needs phenological stations network. Curr. Sci. 95: 832-834.

Kushwaha C.P. and Singh K.P., 2005. Diversity of leaf phenology in a tropical deciduous forest in India. J. Trop. Ecol. 21: 47-56.

Lim P.O., Kim H.J., and Nam H.G., 2007. Leaf senescence. Ann. Rev. Plant Biol. 58: 115-136.

Niinemets U., 1999. Research review. Components of leaf dry mass per area - thickness and density - alter leaf photosynthetic capacity in reverse directions in woody plants. New Phytol. 144: 35-47.

Olivares E. and Medina E., 1992. Water and nutrient relations of woody perennials from tropical dry forest. J. Veg. Sci. 3: 383-392.

Poorter L., 2008. The relationships of wood-, gas- and water fractions of tree stems to performance and life history variation in tropical trees. Ann. Bot. 102: 367-375.

Prior L.D., Eamus D., and Bowman D.M.J.S., 2003. Leaf attributes in the seasonally dry tropics: a comparison of four habitats in northern Australia. Funct. Ecol. 17: 504-515.

Reich P.B., walters M.B., and Ellsworth D.S., 1997. From tropics to tundra: Global convergence in plant functioning. Proc. Natl. Acad. Sci. USA 94: 13730-13734.

Reich P.B., Walters M.B., and Ellsworth D.S., 1992. Leaf life-span in relation to leaf, plant and stand characteristics among diverse ecosystems. Ecol. Monogr. 62: 365-392.

Rivera G., Elliott H., Caldas L.S., Nicolossi G., Coradin V.T.R., and Borchert R., 2002. Increasing day-length induces spring flushing of tropical dry forest trees in the absence of rain. Trees 16: 445-456.

Roderick M.L., 2000. On the measurement of growth with applications to the modeling and analysis of plant growth. Funt. Ecol. 14: 244-251.

Seiwa K., Kikuzawa K., Kadowaki T., Akasaka S., and Ueno N., 2005. Shoot life span in relation to successional status in deciduous broadleaved tree species in a temperate forest. New Phytol. 169: 537-548.

Singh K.P. and Kushwaha C.P., 2005a. Emerging paradigms of tree phenology in dry tropics. Curr. Sci. 89: 964-975.

Singh K.P. and Kushwaha C.P., 2005b. Paradox of leaf phenology: Shorea robusta is a semi-evergreen species in tropical dry deciduous forests in India. Curr. Sci. 88: 1820-1824.

Singh K.P. and Kushwaha C.P., 2006. Diversity of flowering and fruiting phenology of trees in a tropical deciduous forest in India. Ann. Bot. 97: $265-276$.

Wright I.J., Reich P.B., Cornelissen J.H.C., Falster D.S., Groom P.K., Hikosaka K., Lee W., Lusk C.H., Niinemets U., Oleksyn J., Osada N., Poorter H., Warton D.I., and Westoby M., 2005. Modulation of leaf economic traits and trait relationships by climate. Glob. Ecol. Biogeogr. 14: 411-421.

Wright I.J., Reich P.B., Westoby M., Ackerly D.D., Baruch Z., Bongers F., Cavender-Bares J., Chapin F.S., Cornelissen J.H.C., Diemer M., Flexas J., Garnier E., Groom P.K., Gulias J., Hikosaka K., Lamont B.B., Lee T., Lee W., Lusk C., Midgley J.J., Navas M.-L., Niinemets U., Oleksyn J., Osada N., Poorter H., Poot P., Prior L., Pyankov V.I., Roumet C., Thomas S.C., Tjoelker M.G., Veneklaas E.J., and Villar R., 2004. The world-wide leaf economics spectrum. Nature 428: 821-827.

Yoshifugi N., Kumagai T., Tanaka K., Tanaka N., Komatsu H., Suzuki M., and Tantasirin C., 2006. Interannual variation in growing season length of a tropical seasonal forest in northern Thailand. For. Ecol. Manage. 229: 333-339. 